\title{
A sickle boat petroglyph in Wadi Asafir: possible evidence of Pre-Dynastic Egyptian influence on North-west Arabia
}

\author{
Ömer Can Aksoy* \\ * Teos Heritage, Izmir, Turkey (₫o.aksoy@ucl.ac.uk)
}

A sickle boat petroglyph in Wadi Asafir, North-west Arabia, can potentially stretch the geographic scope of the connection between Egypt and Western Arabia in the fourth millennium BC.

Keywords: Saudi Arabia, Pre-Dynastic Egypt, rock art, sickle boat

\section{Introduction}

The interaction between North-west Arabia and Egypt is demonstrated mainly by the Late Bronze Age and Iron Age finds from oasis settlements in North-west Arabia (Sperveslage \& Eichmann 2012: 372). In contrast, the features of this connection are relatively vague when considering the Pre-Dynastic period. The present argument for possible Pre-Dynastic networks across the Red Sea rests on obsidian and lapis lazuli finds from a number of Egyptian and Arabian sites, and on the boat petroglyphs concentrated in the Eastern Desert (Zarins 2009: 93-96; Khalidi 2010; Giménez et al. 2015; Sperveslage 2019: 249-52). This article introduces a sickle boat petroglyph that demonstrates the potential to stretch the geographic scope of the relationship between Egypt and Western Arabia in the fourth millennium BC. In 2014, the boat petroglyph was recorded by the author on a sandstone hill in Wadi Asafir; $18 \mathrm{~km}$ south-west of Tabuk and roughly $130 \mathrm{~km}$ away from the nearest coastline of the Red Sea (Figure 1).

\section{Location and context}

The sandstone hill overlooks Road 8900, which crosses the series of valleys between Tabuk and the Medina Region and is connected to the road between Tabuk and the pre-Islamic coastal site of Aynunah. Given the high density of petroglyphs and Thamudic, Nabatean and Safaitic inscriptions in the proximity of Road 8900, it is safe to assume that the Wadi Asafir boat is located in an ancient locus of movement. The boat image is on a sandstone boulder, which was seemingly detached from the rocky peak of the hill. Relatively fresh deformations on the edges of the rock around the boat petroglyph and the presence of reversed anthropomorphic figures on a rock that was apparently detached from the outcrop of the hill (Figure 2) suggest that the Wadi Asafir sickle boat petroglyph is not in situ. The possibility

Received: 29 December 2019; Revised: 24 March 2020; Accepted: 8 April 2020

(C) The Author(s), 2020. Published by Cambridge University Press on behalf of Antiquity Publications Ltd 


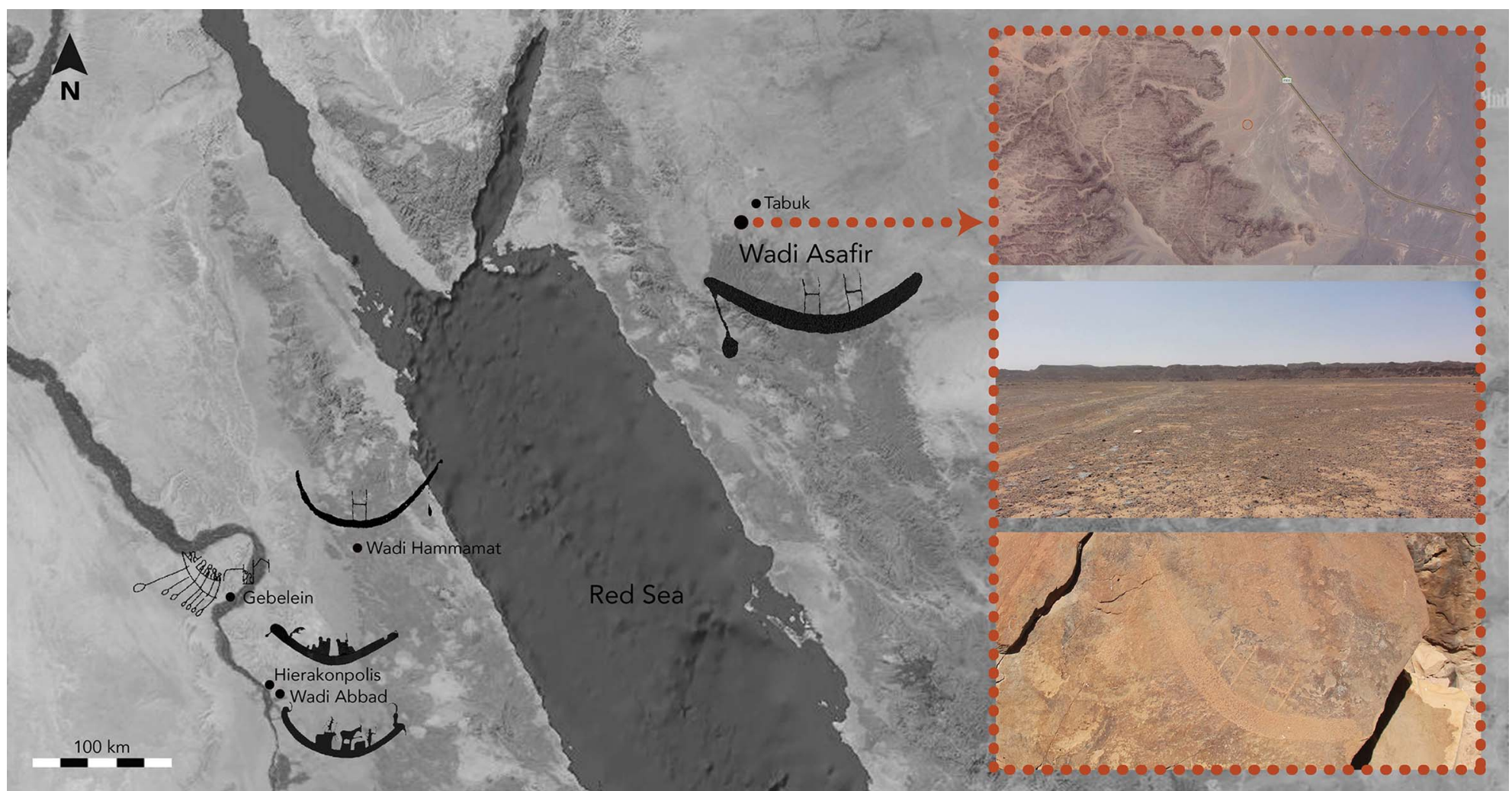

Figure 1. Left) location map showing sites of comparative sickle-shaped boat figures in Egypt; right) the Wadi Asafir petroglyph, with site detail (Google Earth map, edited by G. Kahraman-Aksoy). 


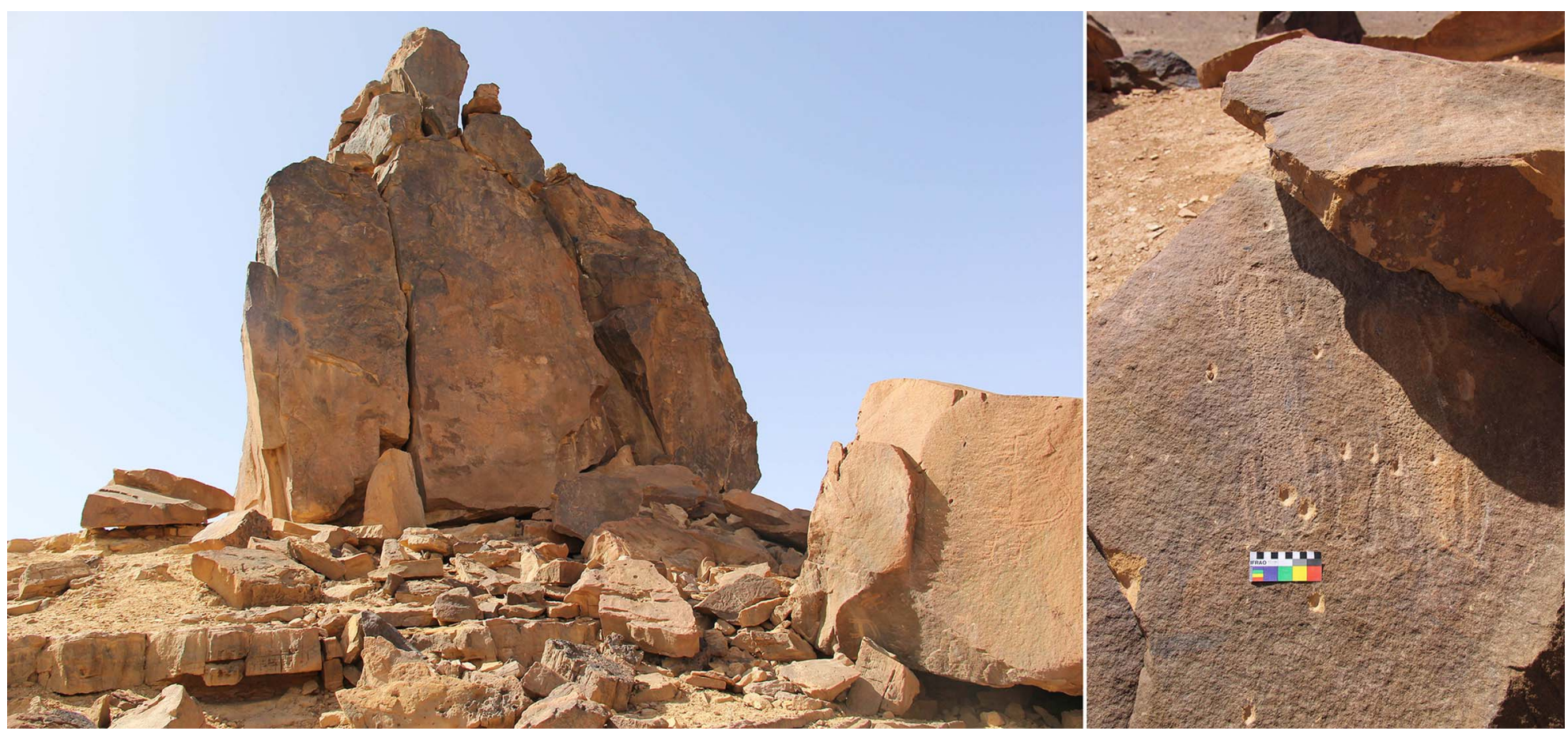

Figure 2. Left) the peak of the hill at Wadi Asafir; right) reversed anthropomorphic figures on a boulder that was apparently detached from the peak of the hill (photographs by C. Aksoy). 
of the boat figure being part of a larger composition is unclear from the present distribution of petroglyphs on the hill; different methods of application and layers of patina were detected on various rock art figures in the proximity of the boat petroglyph.

\section{Design}

The Wadi Asafir boat is composed of a sickle-shaped hull, two $\mathrm{H}$-shaped structures on the deck and a large circular object placed at the end of a tapering line that is inclining $45^{\circ}$ counter-clockwise from the left end of the hull (Figure 3). It is unclear which end of the hull is the stern and which is the prow as both ends are identical. The tapering line and circular object could be interpreted as an oar because it was positioned at one of the curved ends of the hull. Alternatively, this feature could be viewed as a representation of an anchor due to the $45^{\circ}$ angle and V-shaped connection between line and hull. Equally, this could simply be the artist's miscalculation in an attempt to fit the oar or anchor within the contours of the rock face. As no paddles or crew are visible in the composition, it is difficult to attest whether the petroglyph displays a rowing boat or a sailing boat. To this end, H-shaped structures on the deck could be interpreted as bipod masts. In Egyptian and Mesopotamian depictions of boats on rocks and seals, these were often rigged to reed bundle boats (Carter 2012: 350). Yet, the poles of these H-shaped structures on the Wadi Asafir boat do not appear to be secured together at the top, forming a triangle. Therefore, we cannot rule out the possibility that these installations on the deck were cabins.

\section{Possible origins}

Based on the sickle shape of the hull, the origin of the boat could be anywhere as this form was adopted widely in various parts of the world (Gilbert 1999; McGrail 2004: 20; Pomey 2019). Together with the other features, the shape of the hull of the Wadi Asafir boat however manifests Egyptian traits of the fourth millennium BC. The low curved form of the Wadi

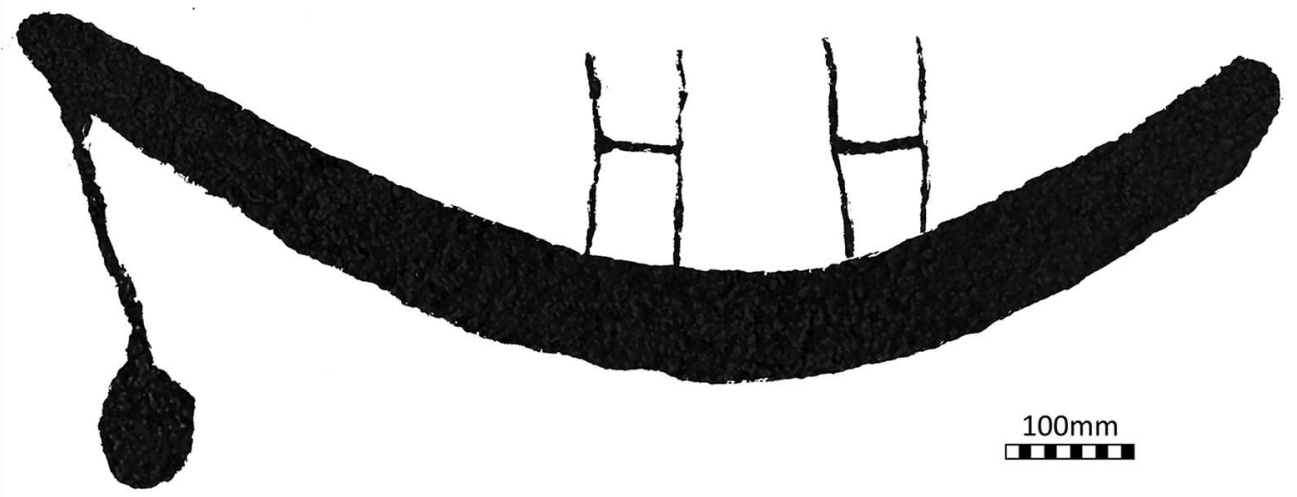

Figure 3. Tracing of the Wadi Asafir boat petroglyph (tracing by C. Aksoy)

(C) The Author(s), 2020. Published by Cambridge University Press on behalf of Antiquity Publications Ltd 
Asafir boat hull resembles rock art representations of boats in Kanais/Wadi Abbad and the Hierakonpolis mural (Mark 1997: 77-78; Rohl 2000: 129) (Figure 1).

The H-shaped structures on the deck of the Wadi Asafir boat show similarities to the deck structures of a sickle boat petroglyph in Wadi Hammamat and two sickle boat images on a linen fragment found in a fourth-millennium BC tomb at El-Gebelein (Figure 1). In the case of El-Gebelein, deformed anthropomorphic figures were shown inside these H-shaped structures. This comparison supports the theory that the H-shaped structures on the Wadi Asafir boat represent cabins. It is impossible, however, to verify whether the El-Gebelein structures were cabins for passengers or shrines for deities due to the poor preservation of the linen (McGrail 2004: 19). Likewise, Wadi Asafir boat's relative simplicity in comparison to the Egyptian examples does not allow us to attribute any function to the boat. The supposed marks of authority, religion and utility evident on the Nagada II pottery and Wadi Hammamat petroglyphs of sickle-boats - such as insignias, chequerboard structures, a banner-like device, poles and paddles_-were not apparent on the Wadi Asafir boat.

\section{Conclusions}

The questions arising from the comparisons above are: were the sickle-shaped boats used in the Red Sea in the fourth millennium BC and were there well-established connections between the Egyptian and Arabian sides of the Red Sea during that period? Sickle-shaped boats were defined as riverine boats by Mark (1997: 70-83); this was based on distance of Wadi Hammamat petroglyphs from the Red Sea $(80 \mathrm{~km})$ and their concentration in the valleys open to the Nile. Furthermore, Hartung (2001: 332-35) suggests that these boats were used only on the Nile. In contrast, the sickle boat images on the Jebel Arak knife handle provoked a number of theories for their inspiration, ranging from the sea routes between Egypt and Mesopotamia to artistic influence through glyptic art (Carter 2012). While the Wadi Asafir boat extends the scope of these debates, it does not provide a clear answer as the sickle-shaped boat images are not a common feature of Arabian rock art. Given the $130 \mathrm{~km}$ distance of Wadi Asafir from the Red Sea and its location on the Pre-Islamic and modern day routes in Arabia, we must not rule out the likelihood of an exceptional case of an artistic influence from Egypt via a land route. The place of the Wadi Asafir boat in Egyptian-Arabian relations has yet to be precisely established. The resemblance that it shares with the Egyptian art of the fourth millennium BC, however, suggests that a comprehensive survey targeting the course of Wadi Asafir may help to contextualise the petroglyph in the wider regional network.

\section{Acknowledgements}

The survey was supported by University College London with the permission of the Saudi Commision for Tourism and National Heritage. I am grateful to Dorian Vanhulle, Robert Carter and Jamal Omar for their support.

\section{Funding statement}

The survey was funded by University College London. 


\section{References}

Carter, R. 2012. Watercraft, in D.T. Potts (ed.) $A$ companion to the archaeology of the ancient Near East: 347-54. Chichester: Wiley-Blackwell. https://doi.org/10.1002/9781444360790.ch19

Gilbert, G.P. 1999. Some notes on prehistoric decorated vessels with boat scenes. Bulletin of the Australian Centre for Egyptology 10: 19-38.

GimÉnez, J., J.A. SÁnchez \& L. Solano. 2015. Identifying the Ethiopian origin of the obsidian found in Upper Egypt (Naqada period) and the most likely exchange routes. Journal of Egyptian Archaeology 101: 349-59. https://doi.org/10.1177/030751331510100122

Hartung, U. 2001. Umm el-Qaab II. Importkeramik aus dem Friedhof U in Abydos (Umm el-Qaab) und die Beziehungen Ägyptens zu Vorderasien im 4. Jahrtausend v. Chr. Mainz: Philipp von Zabern.

Khalidi, L. 2010. Holocene obsidian exchange in the Red Sea region, in M.D. Petraglia \& J.I. Rose (ed.) Vertebrate paleobiology and paleoanthropology: 27991. London \& New York: Springer. https://doi.org/10.1007/978-90-481-2719-1_19

MARK, S. 1997. From Egypt to Mesopotamia: a study of Pre-Dynastic trade routes. College Station: Texas A\&M University Press.
McGraiL, S. 2004. Boats of the world: from the Stone Age to medieval times. Oxford: Oxford University Press.

Pomey, P. 2019. The rock engravings of boats of Sinai and the Pharaonic maritime expeditions, in A. Manzo, C. Zazzaro \& D.J. De Falco (ed.) Stories of globalisation: the Red Sea and the Persian Gulf from late prehistory to early modernity: 13-29. Leiden: Brill. https://doi.org/10.1163/9789004362321_003

RoHL, D. 2000. The followers of Horus: Eastern Desert survey report, volume 1. Abingdon: Institute for the Study of Interdisciplinary Sciences.

Sperveslage, G. 2019. Ägypten und Arabien. Ein Beitrag zu den interkulturellen Beziehungen Altägyptens Alter Orient und Altes Testament (AOAT) 420. Münster: Ugarit.

Sperveslage, G. \& R. Eichmann. 2012. Egyptian cultural impact on North-west Arabia in the second and first millennia BC. Proceedings of the Seminar for Arabian Studies 42: 371-84.

Zarins, J. 2009. Obsidian in the larger context of PreDynastic/Archaic Egyptian Red Sea trade, in J. Reade (ed.) The Indian Ocean in antiquity: 89-106. New York: Routledge. 